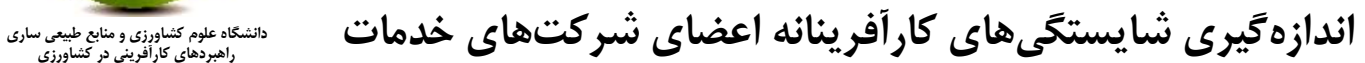

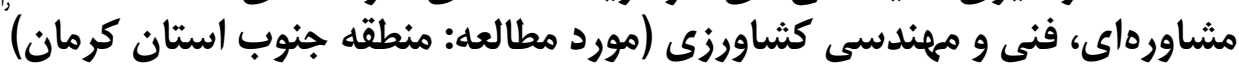

حسام الدين غلامى' و جمشيد اقبالى'

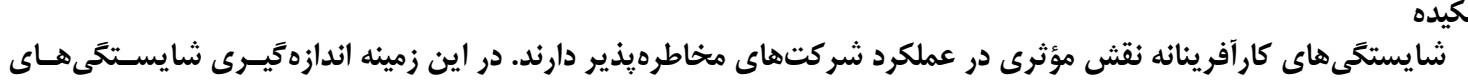

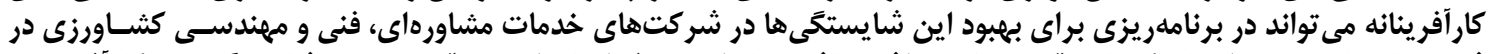

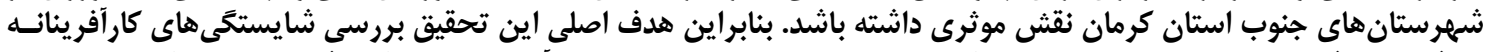

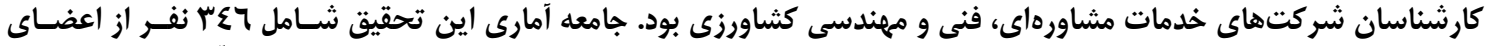

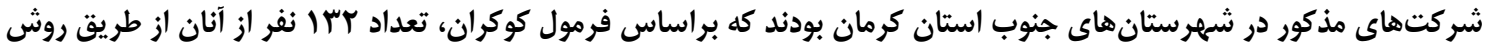

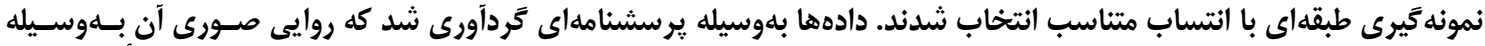

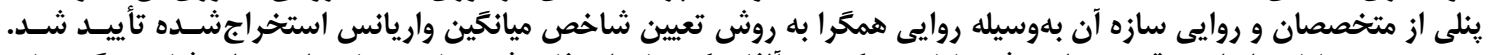

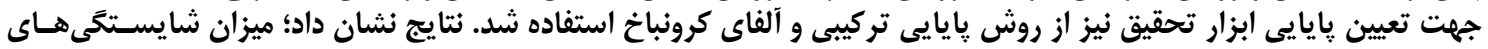

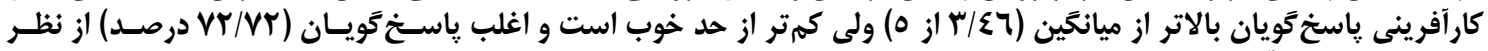

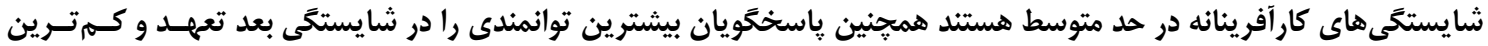

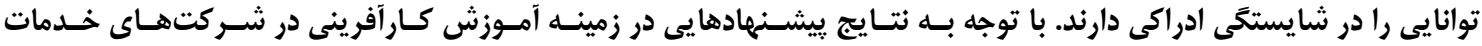
مشاورهاى، فنى و مهندسى ارائه شده است. وازههاى كليدى: شايستكىهاى كارآفرينى، مهارتهاى كارآفرينى، صلاحيت، كسب و كارهاى كثاورزى، دانشآموختكان

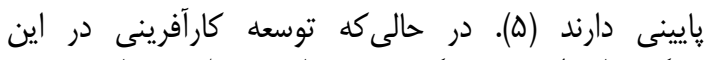

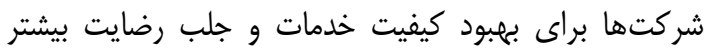

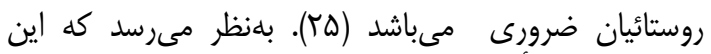

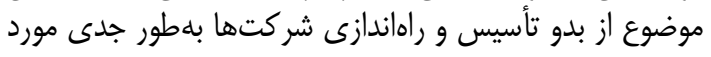

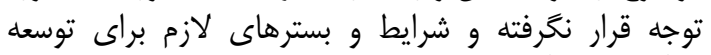
كار آفرينى در آنها فراهم نشده است (1) (1).

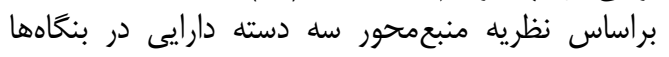

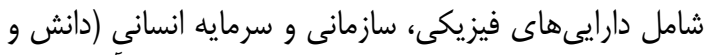

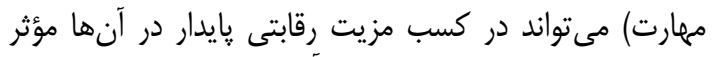

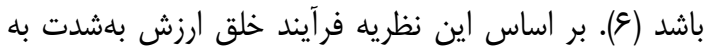

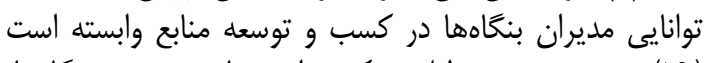

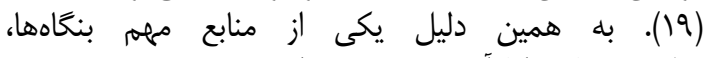

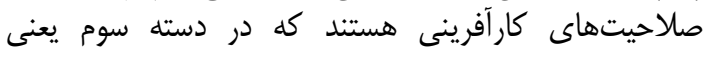

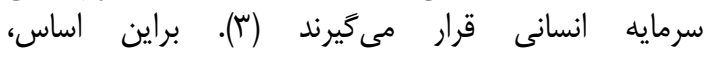

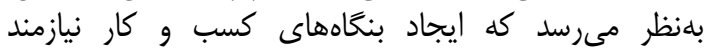

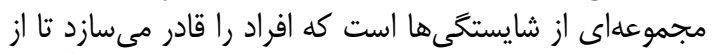

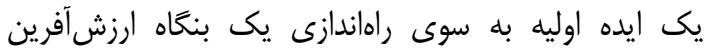

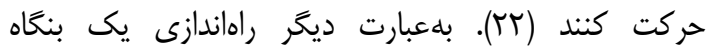

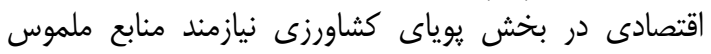

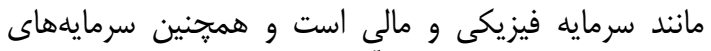

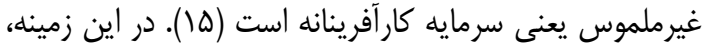

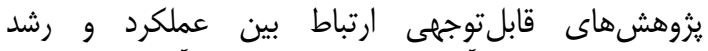

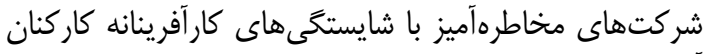

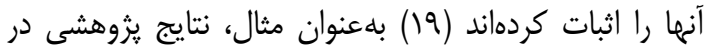
شركتهاى خدمات مشاورهاى، فنى و مهندسى كشاورزى (نئى
كارآفرينى مى تواند باعث تسهيل نوآورى، رشد اقتصادى،

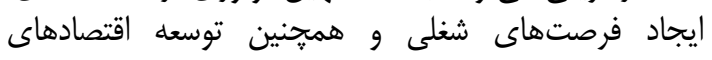

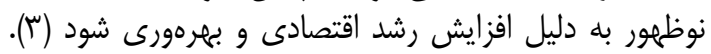

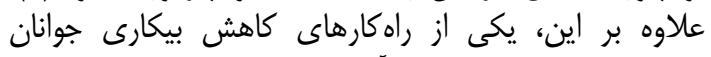

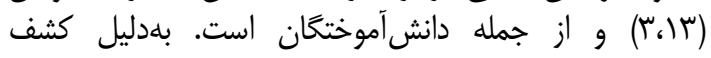

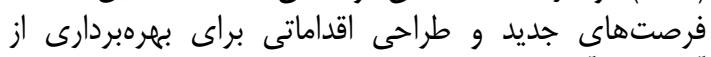

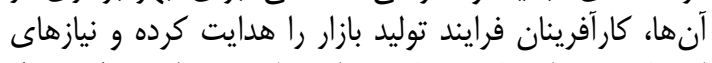

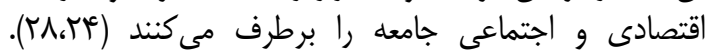
بخش كشاورزى نقش بهانز ايى در توليد ناخالص دارئ داخلى كشور

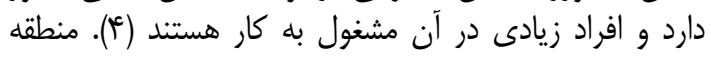

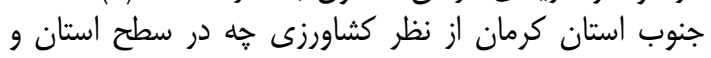

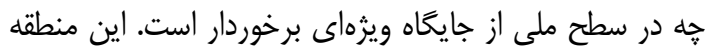

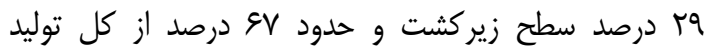

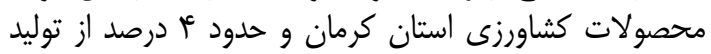

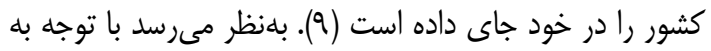

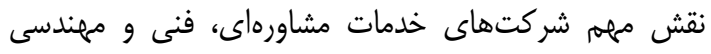

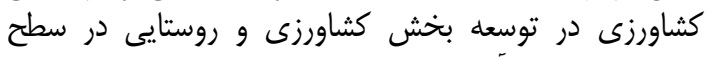

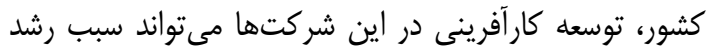

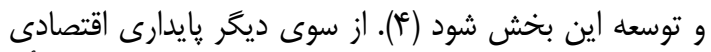

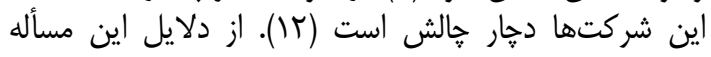

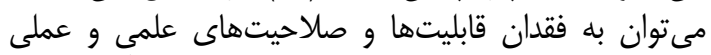

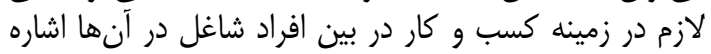

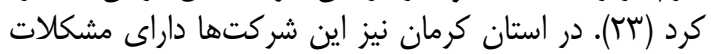

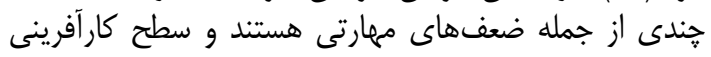




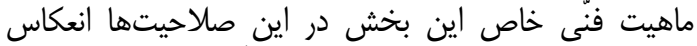

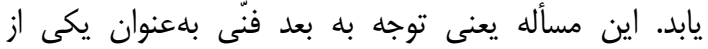

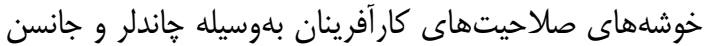

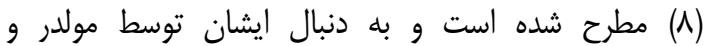

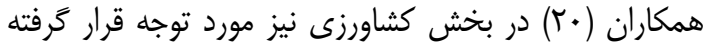

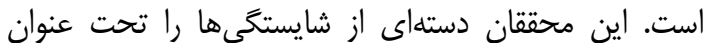

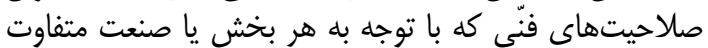

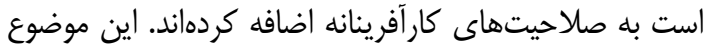

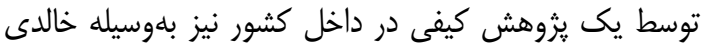

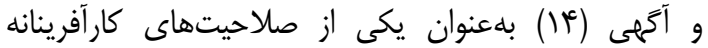

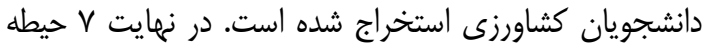

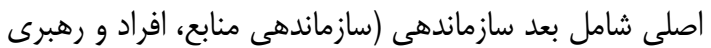

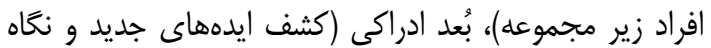

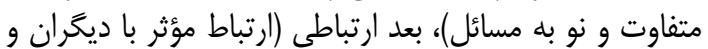

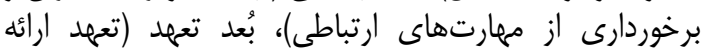

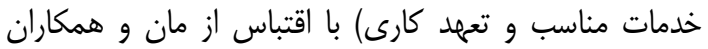
(IV)

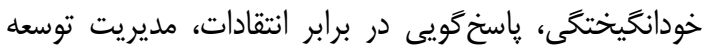

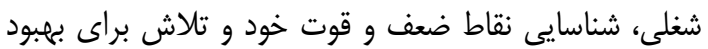

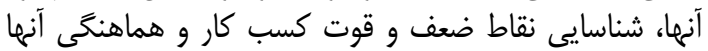

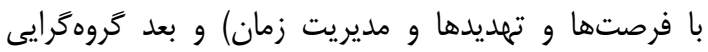

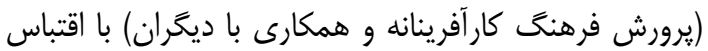

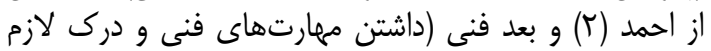

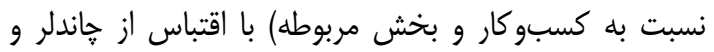

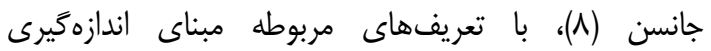
شايستخى هاى كار آفرينانه قرار كَرفتند.

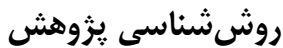

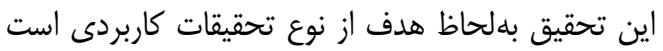

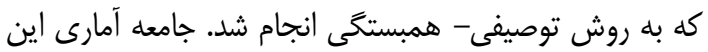
تحقيق را ؤب نفر از اعضاى شركتهاى خداى خدمات مشاورهاى،

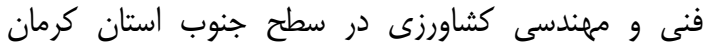

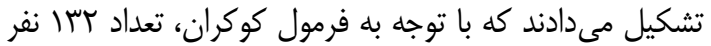

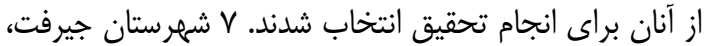

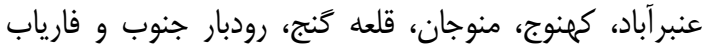

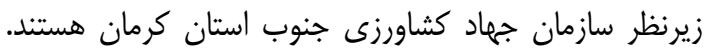

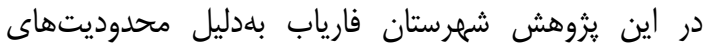

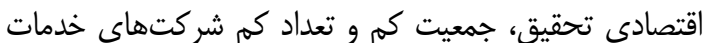

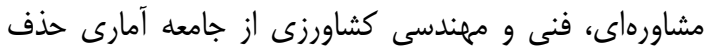

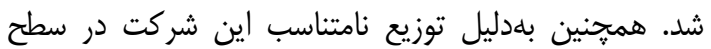

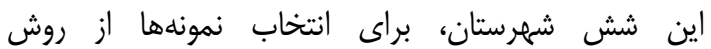
نمونه كَيرى طبقهاى با انتساب متناسب استفاده شد (جدول (1).

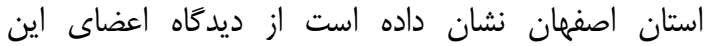

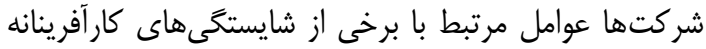

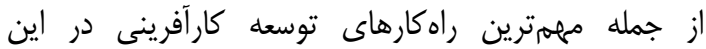

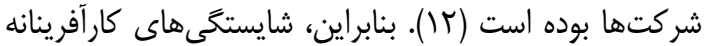

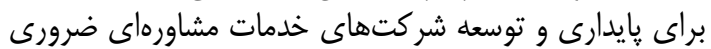

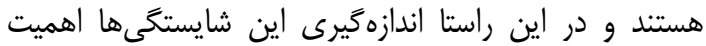

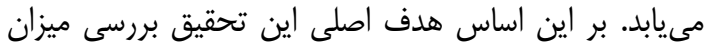

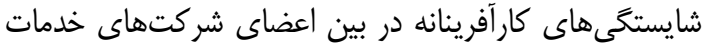

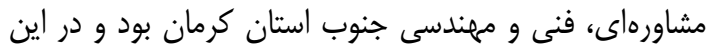

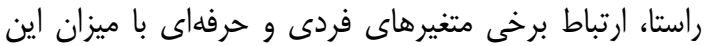

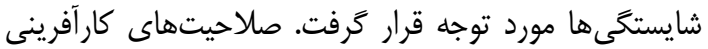

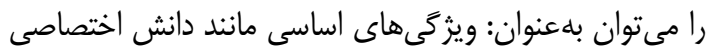

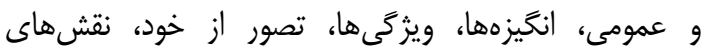

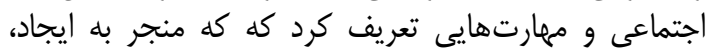

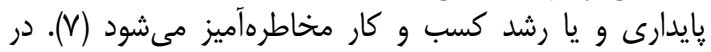
همين زمينه، مان و همكاران (IV) شايستخى كارئ كار آفرينانه،

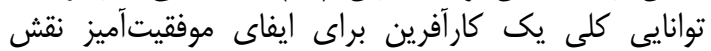

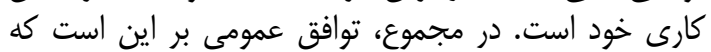

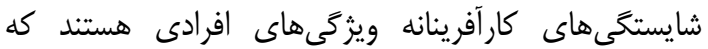

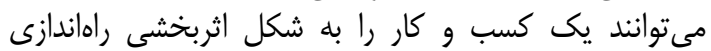

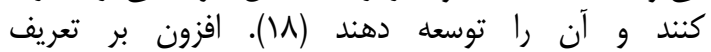

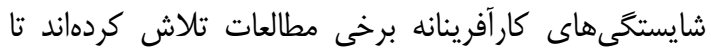

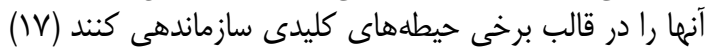

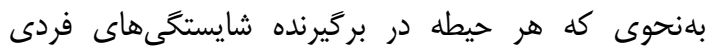

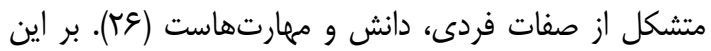

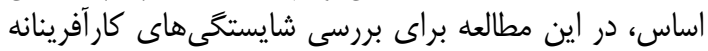

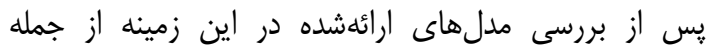

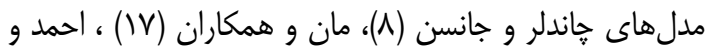

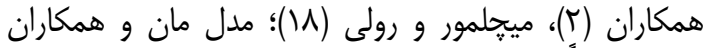
(IV)

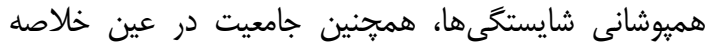

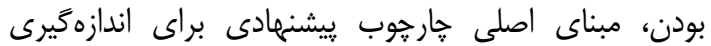

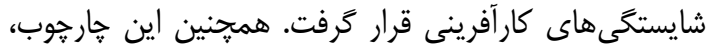

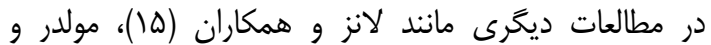

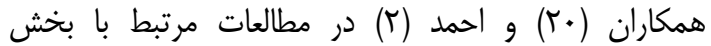

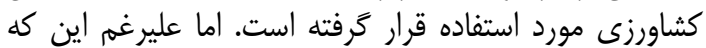

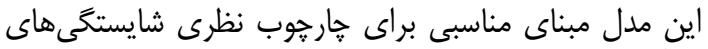

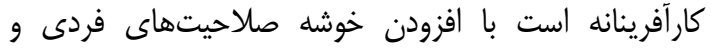

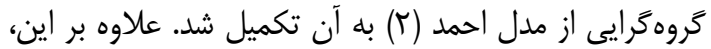

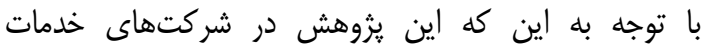
مشاورهاى، فنى و مهندسى كشاورزى انجام مى كيرد؛ بايد خدمات 
جدول 1- تعداد اعضاى شركتها به تفكيك شهرستانها و تعداد نمونههاى اختصاصيافته Table 1. The number of companies' members in townships and the number of samples allocated to each one

\begin{tabular}{|c|c|c|}
\hline تعداد نمونه اختصاص يافته & تعداد كل اعضا در هريك از شهرستانها & 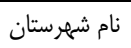 \\
\hline fef & 110 & جيرفت - \\
\hline ra & 91 & عنبرآباد \\
\hline it & r & 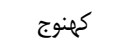 \\
\hline$\wedge$ & ri & 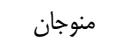 \\
\hline 19 & س & قلعه گنج \\
\hline iv & ra & رودبار جنوب \\
\hline זri & Meg & جمع كل \\
\hline
\end{tabular}

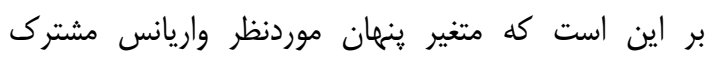

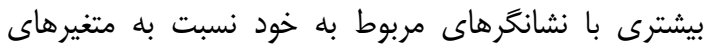

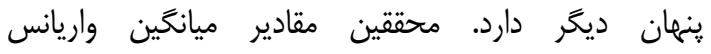

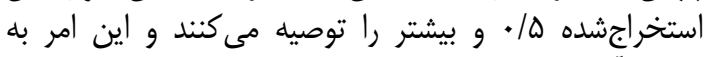

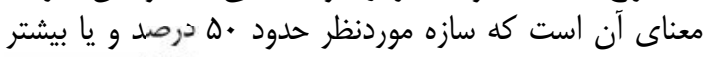

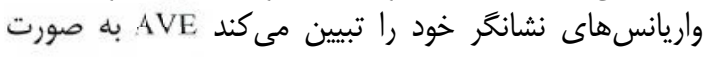
$A V E=\frac{\sum \lambda_{i}^{2}}{n}$ زير محاسبه مى شود:

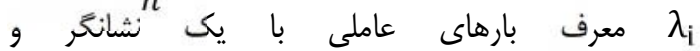
var $\left(\varepsilon_{\mathrm{i}}\right)=1-\lambda_{\mathrm{i} 2}$ كه نتايج مندرج در جدأ

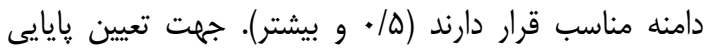

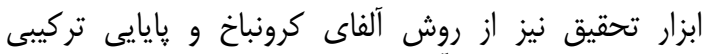

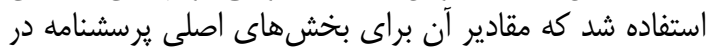

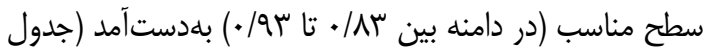

ابزار گردآورى دادهها در اين تحقيق يرسشنامه بود كه از

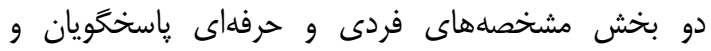

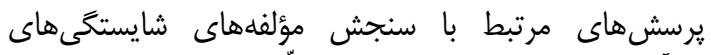

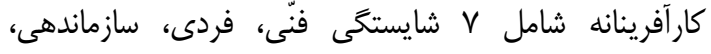

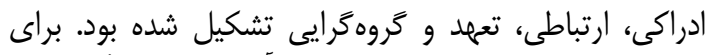

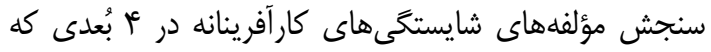

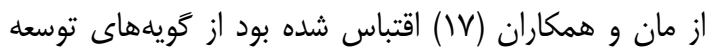

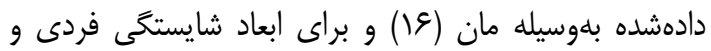

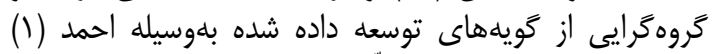

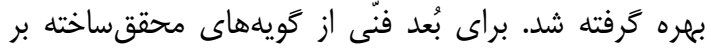

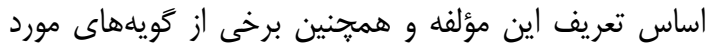

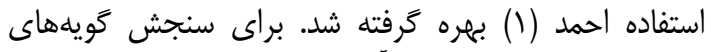

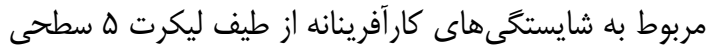

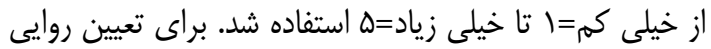

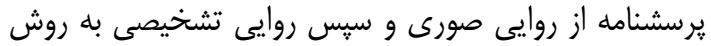

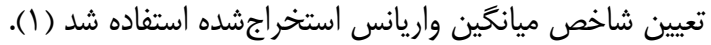

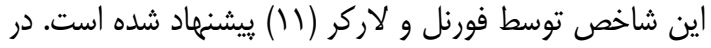

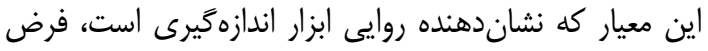

جدول ז- نتايج پايايى و روايى شايستخى هاى كارآفرينانه

Table 2. The reliability and validity of entrepreneurial competencies

\begin{tabular}{|c|c|c|c|c|}
\hline AVE & קايايى تر كيبى & آلفاى كرونباخ & شايستخى & مؤلفه \\
\hline .109 & $\cdot / \mathrm{AV}$ & . INE & شايستخى فنى & \\
\hline.$/ \Delta$. & $\cdot / N$ & - / $\Delta \Delta$ & شايستخى فردى & 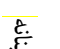 \\
\hline$\cdot / \Delta \Lambda$ &.$/ 94$ &.$/ 91$ & شايستخى سازماندهى & $\underbrace{}_{i}$ \\
\hline.$|Q|$ & $\cdot / M$ & - /AV & شايستخى ادراكى & $a$ \\
\hline$\cdot / \Delta V$ & $\cdot / M$ & $\cdot / A V$ & شايستخى ارتباطى & 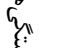 \\
\hline.$/ 49$ & س9/. &.$/ 9 T$ & شايستخى تعهد & $\varepsilon$ \\
\hline .109 & . $/ A F$ & 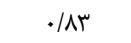 & شايستكى گروه گرايى & \\
\hline
\end{tabular}

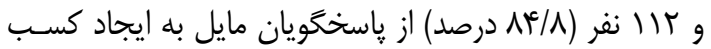

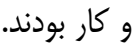

وضعيت پاسخ كَويان از نظر شايستخى هایى كار آفرينانه

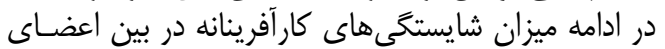

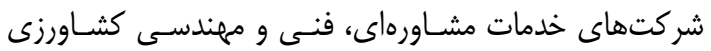

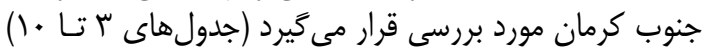

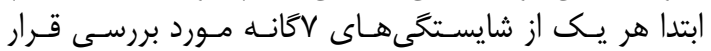

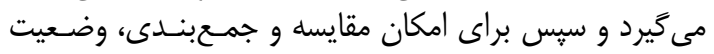

\section{نتايج و بـحث

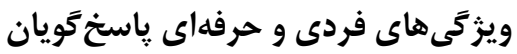

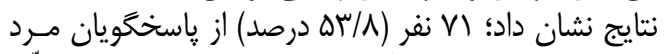

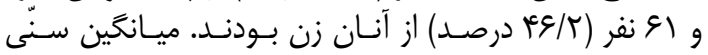

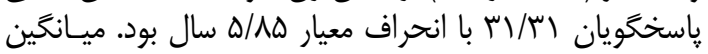

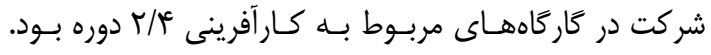

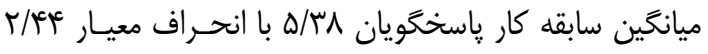

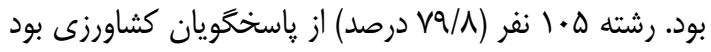


مشاورهاى، فنى و مهندسى كشاورزى در شهرستانهاى دانى

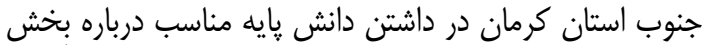

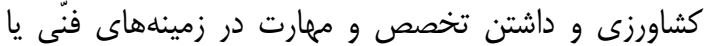

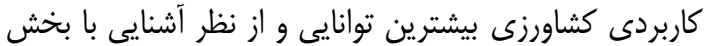

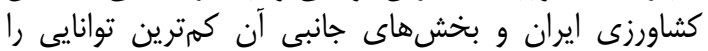

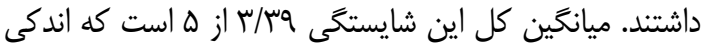

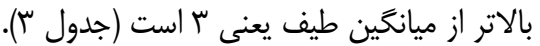

ميانكين كل اين شايستخى ها گزارش خواهد شد (جدول +1 و

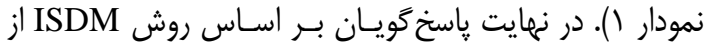

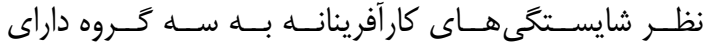

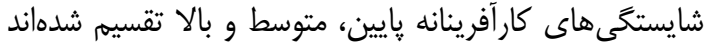
(T).TV) وضعيت پاسخَّويان از نظر شايستَى فنّى

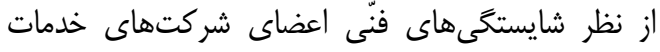

Table 3. Prioritization of technical competencies statements

$$
\text { جدول ب- نتايج اولويتبندى گويههاى شايستخى فنّى }
$$

\begin{tabular}{|c|c|c|}
\hline انحراف معيار & 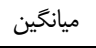 & كويه \\
\hline$\cdot / \wedge \varepsilon$ & $r / \& q$ & داشتن دانش پايه مناسب درباره بخش كشاورزى \\
\hline$\cdot / 9$ & $r / \uparrow q$ & داشتن تخصص و مهارت در زمينههاى فنى يا كاربردى كشاورزى \\
\hline$\cdot / \mathrm{v} \Lambda$ & $r / 49$ & استفاده از تكنيكها يا روشهاى مرتبط با كسب و كار خود \\
\hline - Va & $r / 4 r$ & استفاده از دانش فنى مرتبط با كسب و كار خود \\
\hline.$/ 91$ & $r / r \cdot$ & آشنايى با فرصتهاى موجود در بخش كشاورزى \\
\hline $1 / \pi r$ & $r / \mathrm{IV}$ & آشنايى با بخش كشاورزى ايران و بخشهاى جانبى آن. \\
\hline$\cdot / \mathrm{V}$ & r/\%q & كل كويههl \\
\hline
\end{tabular}

سطح بالايى از انرزى ضعف بيشترى دارند. ميانكين كل اين إناني

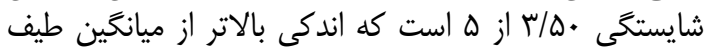

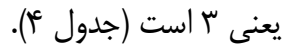

Table 4. Prioritization of personal competencies statements

\begin{tabular}{|c|c|c|}
\hline انحراف معيار & 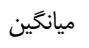 & كويه \\
\hline$\cdot / V \Delta$ & $r / 91$ & ياسخ گو بودن به انتقادات سازنده \\
\hline$\cdot / V \Delta$ & $r / \Delta \Lambda$ & مديريت توسعه شغلى خود \\
\hline$\cdot / \mathrm{V}$ & $r / \Delta r$ & برانكَيختن خود به طورى كه در يك سطح بهينه از عملكرد كار كنيد \\
\hline$\cdot / \Lambda \Delta$ & $r / \mp \wedge$ & اولويتبندى كارها براى مديريت زمان \\
\hline • & $r / 4 \varphi^{4}$ & حفظ نگرش مثبت به مسائل \\
\hline . /At & r/א & حفظ سطح بالايى از انرزى \\
\hline.$/ \Delta S$ & $\Gamma / \Delta$. & كل گويهها \\
\hline
\end{tabular}

\section{وضعيت ياسخ تويان از نظر شايستكى فردى}

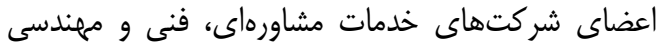

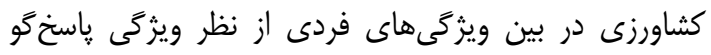
بودن به انتقادات سازنده وضعيت بهترى دارند و از نظر حفظ فئر

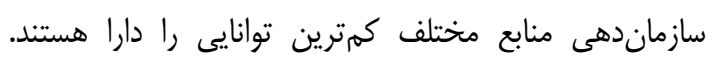

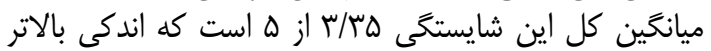

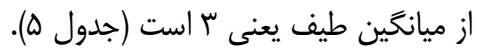

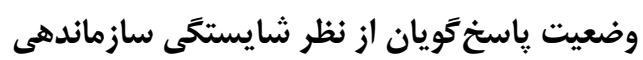

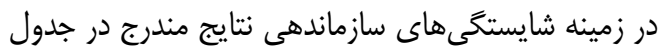

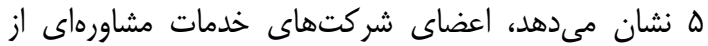

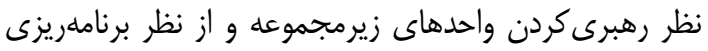


Table 5. Prioritization of organizing competencies statements

جدول ه- نتايج اولويتبندى گويههاى بُعد سازماندهى

\begin{tabular}{|c|c|c|}
\hline انحراف معيار & 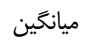 & كويه \\
\hline.$/ 91$ & $r / \uparrow q$ & رهبرى كردن واحدهاى زيرمجموعه \\
\hline $.1 / 9$ & $r / \% \Delta$ & وظايف را هماهنگ كردن \\
\hline.$/ 91$ & $r / \mp \Delta$ & سازماندهى افراد \\
\hline.$/ 91$ & $r / ץ q$ & انكَيزه دادن به افراد \\
\hline.$/ 19$ & r/Tr & برنامهريزى عمليات كسب و كار \\
\hline .198 & $r / r \cdot$ & 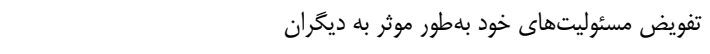 \\
\hline$\cdot / \mathrm{M}$ & $r / r q$ & شركت را بهكَونهاى هدايت مى كنم كه كارهاى آن بهصورت آرام و روان ادامه يابد \\
\hline ./9Y & $r / T \Lambda$ & 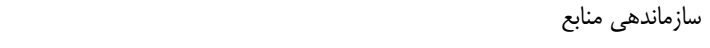 \\
\hline$\cdot / \wedge \Delta$ & $r / T r$ & برنامهر يزى سازماندهى منابع مختلف \\
\hline .191 & $r / r \Delta$ & كل كويهها \\
\hline
\end{tabular}

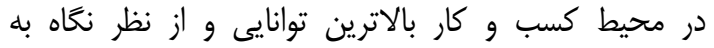

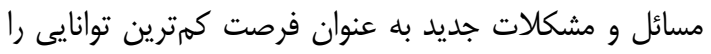

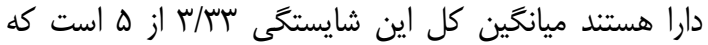

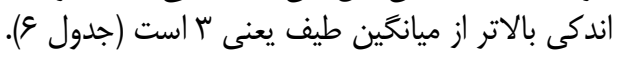

\section{وضعيت پاسخَّويان از نظر شايستخى اداركى}

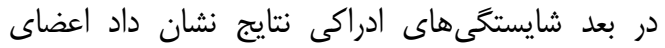

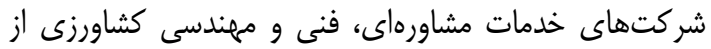

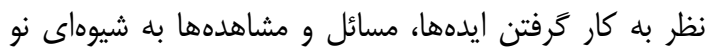

Table 6. Prioritization of conceptual competencies statements

$$
\text { جدول و- نتايج اولويتبندى گويههاى بُعد اداركى }
$$

\begin{tabular}{|c|c|c|}
\hline انحراف معيار & ميانگَين & كويه \\
\hline.$/ A T$ & $r / 4 q$ & به كاركَرفتن ايدهها، مسائل و مشاهدهها به شيواى نو در محيط كسب و كار \\
\hline.$/ 19$ & $r / \kappa \cdot$ & ن تخاه به مسائل به شيوهاى نو \\
\hline . /At & $r / \widetilde{r}$ & درك دامنه زمينههاى كاربست هر بديدهاى كه مشاهده مى كنم، در مقياسى كَسترده \\
\hline.$/ 91$ & $r / \mu r$ & سرعت و هابكى در تصميم كيرىها \\
\hline$\cdot / \mathrm{vq}$ & r/r & كشف ايدههاى جديد \\
\hline$\cdot / \Lambda$ & $r / \mu_{1}$ & نظارت بر فرآيند كار در جهت رسيدن به اهداف در فعاليتهاى داراى ريسك \\
\hline$\cdot / \Lambda \Delta$ & $r / r q$ & نوآور بودن و انجام كارها بهصورتى متفاوت \\
\hline . /At & $r / r \Delta$ & يذيرفتن ريسكهاى متوسط در زمينه شغلى \\
\hline$\cdot / \wedge \mid$ & $r / 19$ & نغخاه به مسائل و مشكلات جديد به عنوان فرصت \\
\hline.$/ 09$ & r & كل كويهها \\
\hline
\end{tabular}

شايستخى ها مربوط به مهارت ارتباط شفاهى است. ميانگين

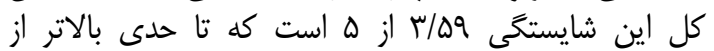

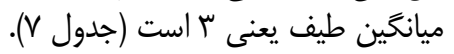

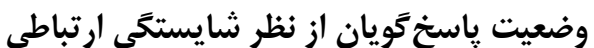

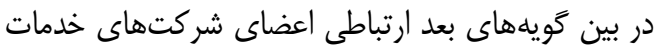

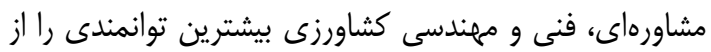

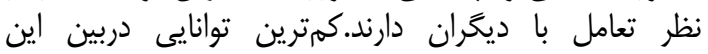
جدول V- نتايج اولويتبندى گويههاى بعد ارتباطى

Table 7. Prioritization of relationship competencies statements

\begin{tabular}{|c|c|c|}
\hline انحراف معيار & 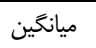 & كويه \\
\hline$\cdot / V q$ & $r / v \varepsilon$ & ت تعامل با ديغران \\
\hline$\cdot|\wedge|$ & $r / 9 V$ & ارتباط مؤثر با ديخران \\
\hline$\cdot / \Lambda \Delta$ & $r / 9 r$ & توسعه روابط بلندمدت بر پايه اعتماد با ديخران \\
\hline . & $r / \Delta \Lambda$ & توانايى مذاكره (هانهزنى) با ديكران \\
\hline$\cdot / v 9$ & $r / \Delta V$ & ايجاد و حفظ شبكهاى شخصى از تماسها و ارتباطات كارى. \\
\hline - ar & $r / 4 \Lambda$ & مهارت ارتباط نوشتارى (مثل انتقال منظور خود از طريق نامه) \\
\hline$\cdot / 1$ & $r / \uparrow \Delta$ & مهارت ارتباط شفاهى (توانايى انتقال منظر خود به طور شفاهى) \\
\hline .94 & $r / \Delta 9$ & كل كويهها \\
\hline
\end{tabular}




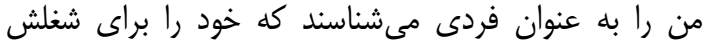

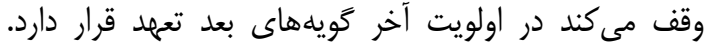

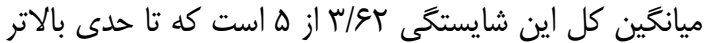

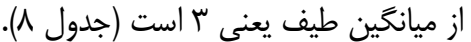

وضعيت ياسخ كَويان از نظر شايستكى تعهد

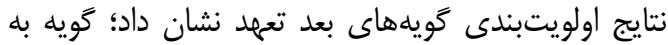

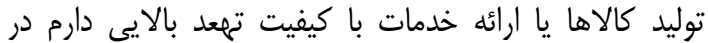

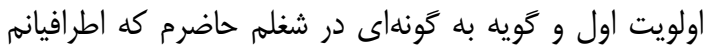

Table 8. Prioritization of commitment competencies statements

$$
\text { جدول ^- نتايج اولويتبندى گويههاى بُعد تعهد }
$$

\begin{tabular}{|c|c|c|}
\hline انحراف معيار & ميانگَين & كويه \\
\hline$\cdot /\left.\Lambda\right|^{c}$ & r/qr & براى موفقيت هر امرى بهخصوص يروزههايى كه در آنها مشاركت دارم از انخيزه بسيار قوى درونى برخوردارم \\
\hline$\cdot / \Lambda \mu$ & r & فكر مى كنم در هر يروزماى از تعهد لازم براى جلوگيرى از شكست كسب و كار مربوطه برخوردارم \\
\hline$\cdot / \mathrm{AV}$ & $r / \Delta \Lambda$ & براى موفقيت هر امرى بهخصوص يروزمهايى كه در آنها مشاركت دارم از انخَيزه بسيار قوى درونى برخوردارم \\
\hline $.19 \mathrm{~V}$ & r/gr & كل گويهها \\
\hline
\end{tabular}

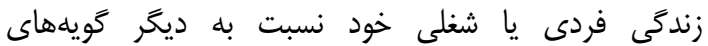

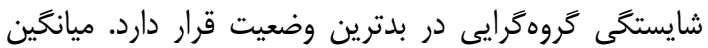

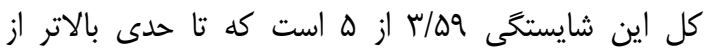

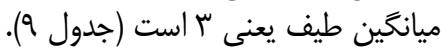

Table 9. Prioritization of familism competencies statements

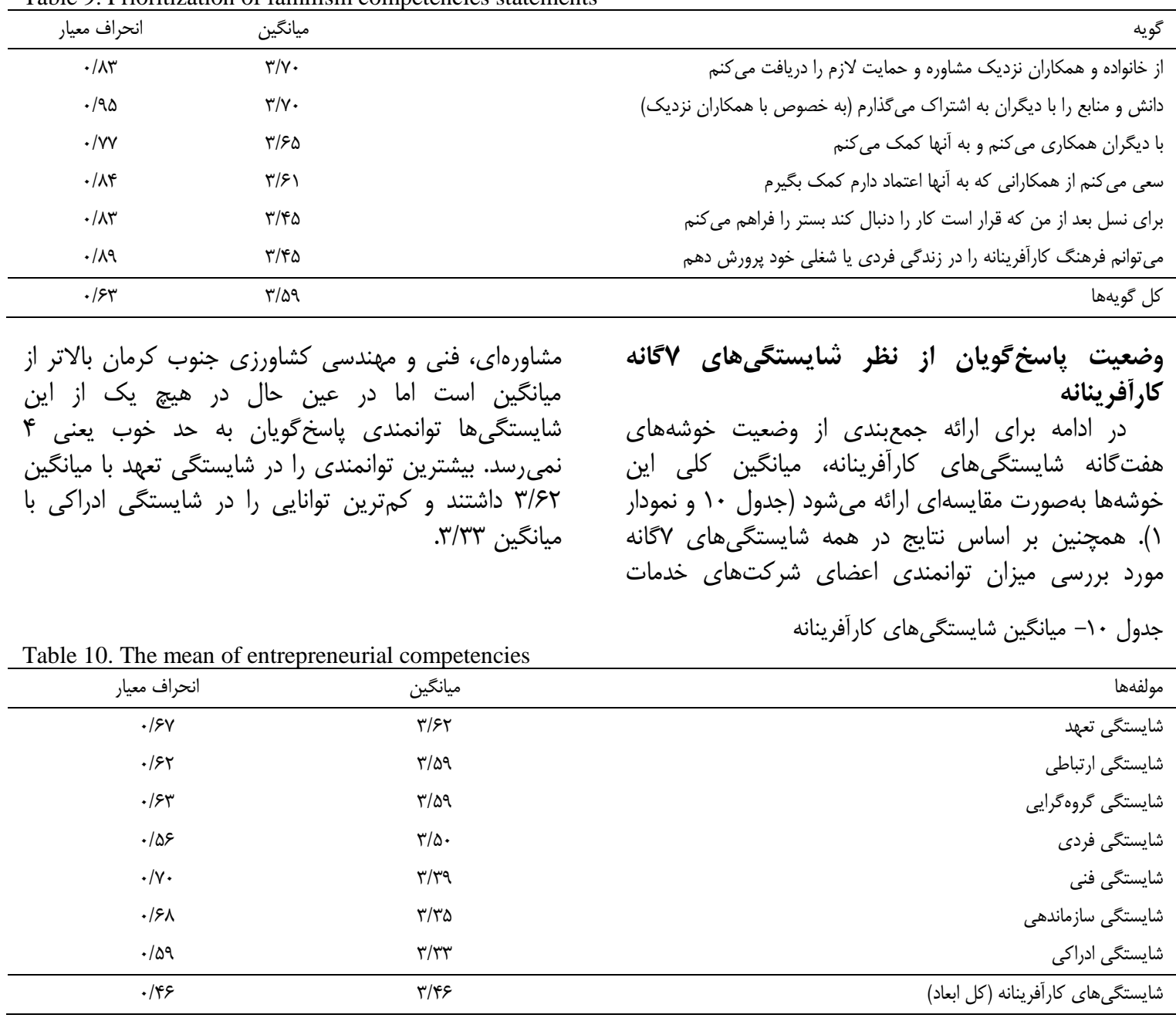

وضعيت ياسخ كَويان از نظر شايستخى كَروهَّرايى

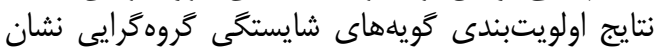

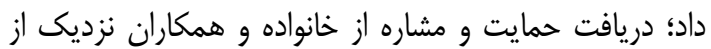

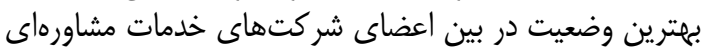
برخوردار است اما توانايى يرورش فرهن اعنى كاريت جدول q- نتايج اولويتبندى گويههاى بُعد گروهرًايى 


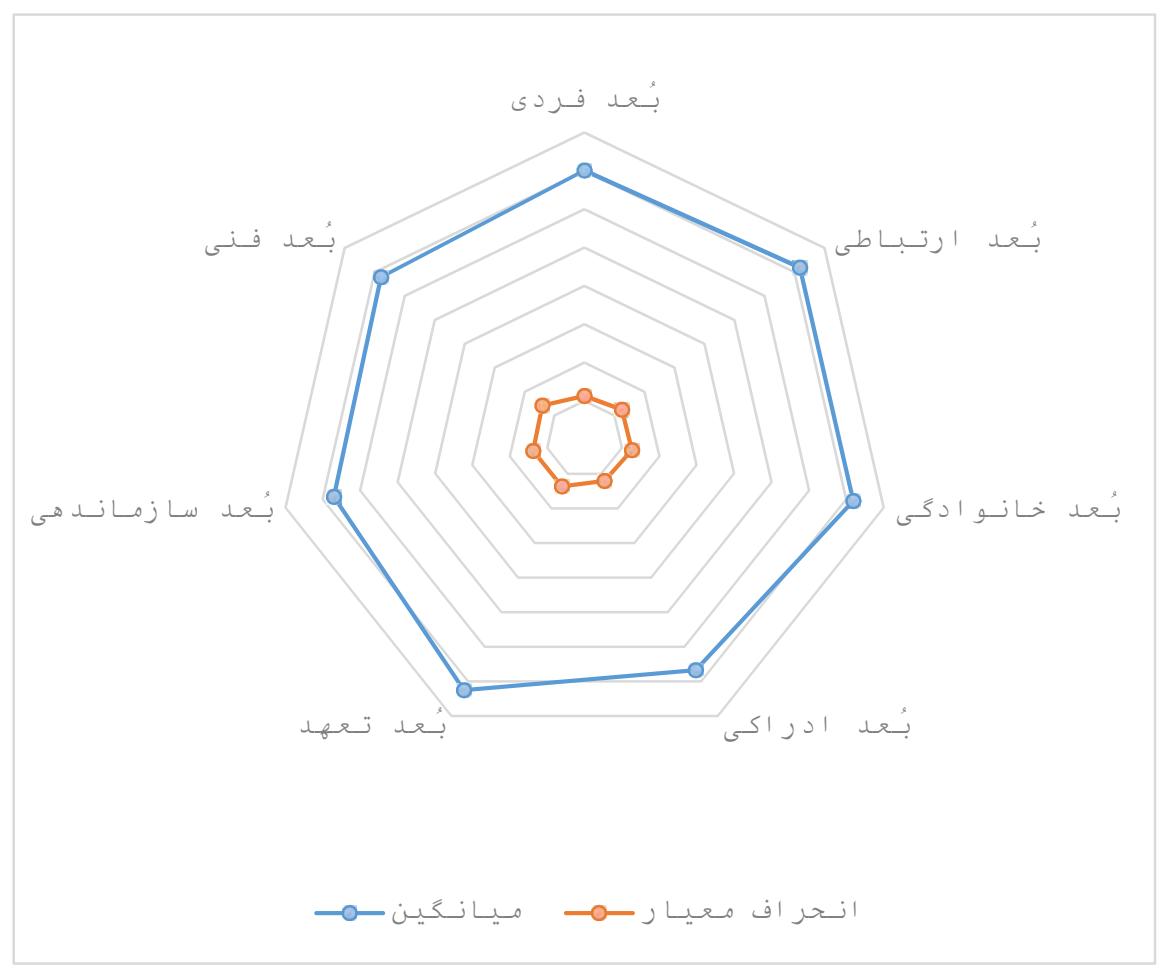

نمودار (1- ميانخين شايستخى هاى كارآفرينانه ياسخ كَويان

Chart 1. The mean of respondents' entrepreneurial competencies

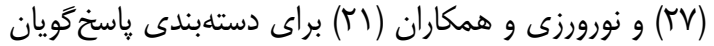

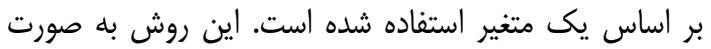
زير انجام مى گيرد.

كم: = A $<$ Mean $-\mathrm{SD}$

B: = Mean -SD < B <Mean +SD

زياد $\mathrm{C}=$ Mean $+\mathrm{SD}<\mathrm{C}$

داراى سطح بالايى از شايستخىهاى كارآفرينانه بودند. خنان

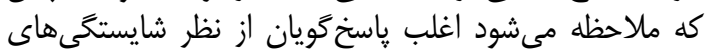
كارآفرينانه در سطح متوسطى قرار دارند.
دستهبندى ياسخ كَيان از نظر ميران شايستخىهاى كار آفرينانه

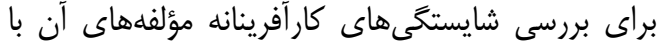

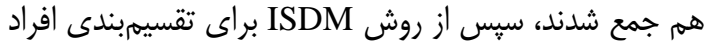

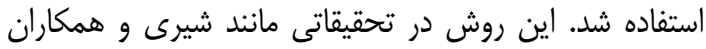

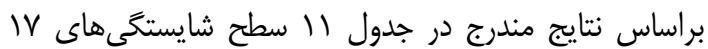

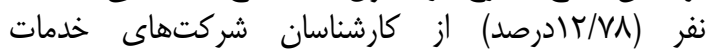

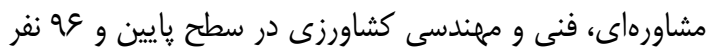

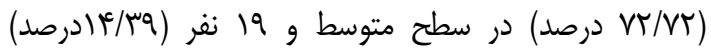

Table 11. Categorizing respondents in terms of entrepreneurial competences

جدول II - طبقهبندى پِاسخَّويان از نظر ميزان شايستخى هاى كارآفرينانه

\begin{tabular}{|c|c|c|}
\hline درصد & فراوانى (نفر) & ميزان \\
\hline$I T / V \Lambda$ & IV & يايين \\
\hline$V T / V T$ & १६ & متوسط \\
\hline $1 f / r q^{2}$ & 19 & بالا \\
\hline $1 .$. & & كل \\
\hline
\end{tabular}




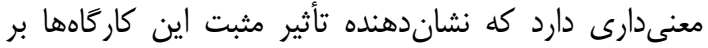

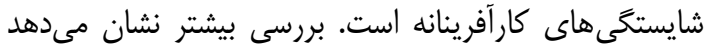

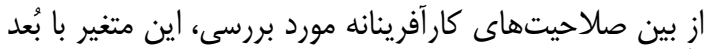

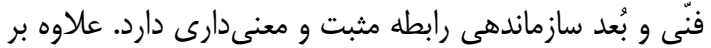

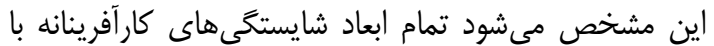

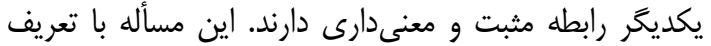

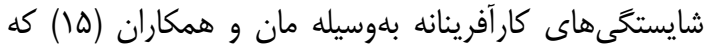

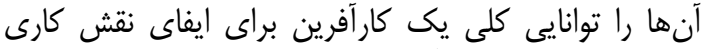

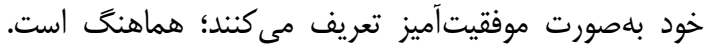

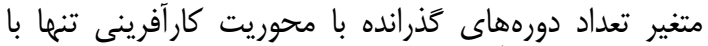

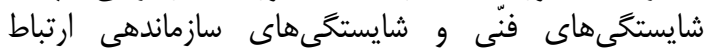
معنى دار داشتند (جدول بائ (I).
بررسى رابطه شايستكى هاى كارآفرينانه با برخى متغير هاى مورد مطالعه راسئر

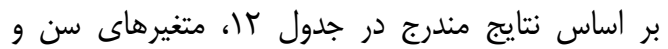
سابقه كار با نمره كل شايستخى هاى كار كار آفرينانه مرتبط است.

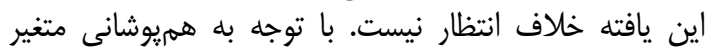

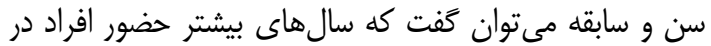

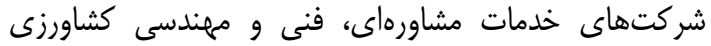

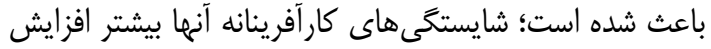

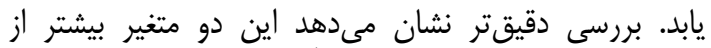

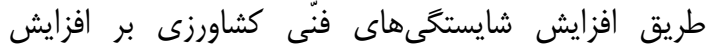

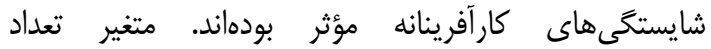

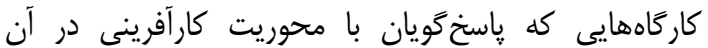

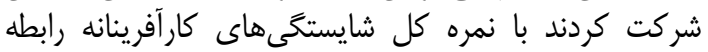

Table 12. Correlational matrix of entrepreneurial competencies and individual and professional characteristics

\begin{tabular}{|c|c|c|c|c|c|c|c|c|c|}
\hline تعداد دور ههاى & شايستخى & شاريستخى & شايستخى ادراكى & شازماندهتى & شايستى شىى & شنى شايستى & سابقه كار & سن & متغير \\
\hline & & & & & & &.$/ \mu V r^{* *}$ & $. / r \mid \varepsilon^{*}$ & شايستخى فنى \\
\hline & & & & & &.$/ F 4 \Lambda^{* *}$ & . MFt & - & شايستخى شخصى \\
\hline & & & & & $\cdot / \Delta \cdot V^{* *}$ &.$|c r|^{* * *}$ & .1 .91 &.$/ 111$ & شازيستخى \\
\hline & & & & $\cdot / \Delta V^{\mu^{* *}}$ & $\cdot / \Delta \mid r^{* *}$ &.$/\left.41\right|^{* *}$ &. $\mid \cdot \Delta 1$ & $.11 \cdot 9$ & شايستخى ادراكى \\
\hline & & &. $\mid 01 f^{* *}$ &.$/ 419^{* *}$ & $\cdot / \kappa v \cdot{ }^{* *}$ & . $/ T r V^{* * *}$ & $\cdot / \cdot \Delta f$ &.$/ 111$ & شايستخى ارتباطى \\
\hline & & $\cdot \mid \Delta \Delta f^{* * *}$ & $\cdot / \kappa \Delta \varphi^{* * *}$ & - $\operatorname{crs} \Lambda^{* *}$ & $\cdot / 4 \cdot v^{* *}$ & . Met & $+1+.1$ &.$/ 1 t^{c}$ & شايستخى تعهد \\
\hline & $\cdot|0|)^{* * *}$ & $\cdot / \Delta \cdot 1^{* *}$ & . &.$/ 4{ }^{2} V^{* *}$ & $\cdot / 4 \uparrow s^{* *}$ & $.119 r^{*}$ & $-.1 .+4 t$ &.$/ 114$ & \\
\hline & $\cdot 1 \cdot \Delta \Lambda$ & .1 .94 & - Mtrt &.$/ 1 F \Delta^{*}$ & . /ISt & $\cdot / r \cdot \Lambda^{*}$ & . MTF &.$/ I T \Delta$ & كارآفرينى دورههاى \\
\hline.$/ 19 r^{*}$ & $.19 \wedge \Delta^{* *}$ & . & $\cdot / \Lambda \cdot r^{* * *}$ & ./Vqr** & - $/ V \Delta V^{* *}$ & $\cdot / \Delta V \Lambda^{* *}$ & $\cdot / T V r^{* *}$ & $\cdot / r \cdot \Lambda^{*}$ & شارآيستخى هائى (كل) \\
\hline
\end{tabular}

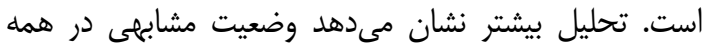

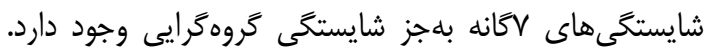

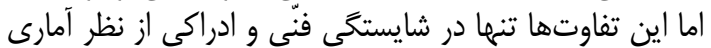

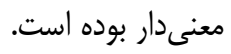

مقايسه ميزان شايستكىهاى كارآفرينانه بين اعضاى زن و مرد

نتايج حاصل از ميزان شايستخىهاى كاردئ مآفرينانه به

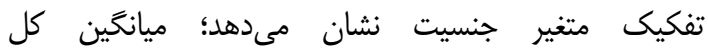
شايستخى هاى كارآفرينانه اعضاى مرد بالاتر از اعضاى زن مين 
جدول سا - مقايسه ميانگين شايستخى هاى كارآفرينانه اعضاى زن و مرد نتايج آزمون t مستقل Table 13. Comparison of means (independent samples t-test) of entrepreneurial competencies of female and male members

\begin{tabular}{|c|c|c|c|c|c|c|}
\hline سطح معنى دارى & مقدارt & انحراف معيار & ميانكين & $\mathrm{N}$ & جنسيت & بُبَد \\
\hline \multirow{2}{*}{ 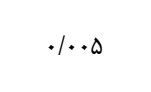 } & \multirow{2}{*}{ r/MAq } & $r / F r V$ & $r M / r$. & n & مرد & شايستخى فنى \\
\hline & & $r / A V{ }^{e}$ & $19 / \pi r$ & 91 & زن & \\
\hline \multirow{2}{*}{ - INAD } & \multirow{2}{*}{.$/ 14 a$} & $Y / \Delta V$ & $r N / \cdot 91$ & vi & مرد & شايستخى شخصى \\
\hline & & $r / \Delta 1 \Lambda$ & TV/Q1 & 81 & زن & \\
\hline \multirow{2}{*}{.$/ 9$} & \multirow{2}{*}{. $/ \Delta T \Delta$} & $8 / \cdot \wedge r$ & r. ( & n & مرد & شايستخى سازماندهى \\
\hline & & G/Fr & $r 9 / \wedge \& \Lambda$ & 81 & زن & \\
\hline \multirow{2}{*}{.$/ . r}$. & \multirow{2}{*}{ T/MGT } & D/ET & $r / . r$ & v. & مرد & شايستخى ادراكى \\
\hline & & $\Delta / / f$ & rN/AKG & 81 & زن & \\
\hline \multirow{2}{*}{ - TAY } & \multirow{2}{*}{$1 / .91$} & $r / 41$ & $r \Delta / \Delta r$ & n & مرد & شايستخى ارتباطى \\
\hline & & r & $M F / V$. & 81 & زن & \\
\hline \multirow{2}{*}{ ( } & \multirow{2}{*}{$1 / \Delta 98$} & $\Gamma / M$ & $M \Delta S T$ & n & مرد & شايستخى تعهد \\
\hline & & $\Gamma / \Delta \Lambda \mu$ & IV 9 r & 81 & زن & \\
\hline \multirow{2}{*}{$\cdot / \Lambda \cdot V$} & \multirow{2}{*}{ - MFa } & r/q & $r / / \leftarrow q$ & $n$ & 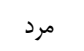 & شايستخى گروهر ايى \\
\hline & & $\Gamma / \varepsilon_{0}$ & $r I /{ }^{\prime} \Delta$ & 81 & زن & \\
\hline \multirow{2}{*}{.$/ 11$} & \multirow{2}{*}{$1 / \Delta \Lambda$} & $\Gamma / \Gamma \Delta$ & IVA/TA & n & مرد & شايستخى هاى \\
\hline & & $r Y / G \Lambda$ & $199 / 9$ & 81 & زن & \\
\hline
\end{tabular}

نتايج اين آزمون نشان مىدهد؛ افرادى كه مايل به راهاندازى كإنى

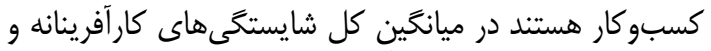

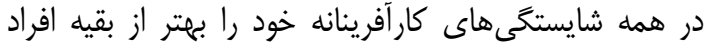

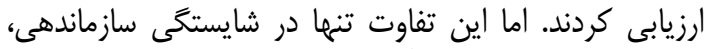

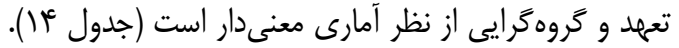

مقايسه ميزان شايستكى هاى كارآفرينانه به تفائ تفكيك

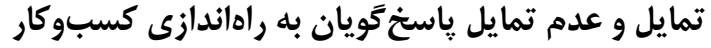

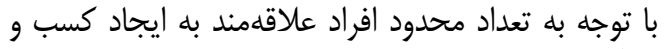

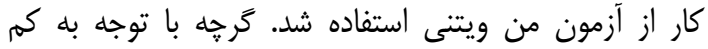

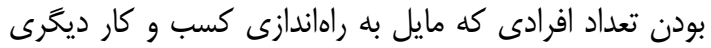

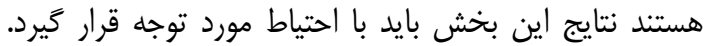

جدول عأ- مقايسه شايستخى هاى كارآفرينانه بين افراد داراى تمايل به راه اندازى كسب وكار و بدون تمايل (آزمون من-ويتنى) Table 14. Comparison of means (Mann- Whitney test) in terms of intention to start a business

\begin{tabular}{|c|c|c|c|c|c|}
\hline سطح معنى دارى & مقدار & ميانگين رتبهها & $\mathrm{N}$ & تمايل به راهاندازى كسب و & بُعد \\
\hline \multirow[b]{2}{*}{ - Mat } & \multirow{2}{*}{.$- / r$} & sT/Ar & if & بله & \multirow{2}{*}{ شايستكى فنى } \\
\hline & & G./VQ & $11 \%$ & خير & \\
\hline \multirow{2}{*}{.$/$ rav } & \multirow{2}{*}{$-1 / \cdot+4$} & & 15 & بله & \multirow{2}{*}{ شايستخى شخصى } \\
\hline & & QT/QT & $11 \%$ & 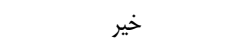 & \\
\hline \multirow{2}{*}{$.1 \cdot 11$} & \multirow{2}{*}{ - I } & $99 / \pi$ & 15 & بله & \multirow{2}{*}{ شايستخى سازماندهى } \\
\hline & & $F / / v a$ & 114 & 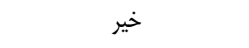 & \\
\hline \multirow{2}{*}{ מזו/. } & \multirow{2}{*}{- M/DFT } & $s \notin / W V$ & 15 & بله & \multirow{2}{*}{ شايستخى ادراكى } \\
\hline & & זN/QS & 114 & خير & \\
\hline \multirow{2}{*}{$\cdot / 9 \Delta F$} & \multirow{2}{*}{$-\cdot / \operatorname{kin}$} & $s \% / \cdot 1$ & 15 & بله & \multirow{2}{*}{ شايستخى ارتباطى } \\
\hline & & $\Delta q / r q$ & 114 & خير & \\
\hline \multirow{2}{*}{$\cdot \cdot \cdot r$} & \multirow{2}{*}{$-r / M$} & $9 g / \Lambda$. & 15 & بله & \multirow{2}{*}{ شايستى تعهد } \\
\hline & & $\mathrm{rV} / \mathrm{M}$ & $11 \pi$ & 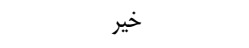 & \\
\hline \multirow{2}{*}{ 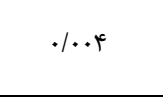 } & \multirow{2}{*}{ - t/NFt } & $99 / \mathrm{V}^{4}$ & 15 & بله & \multirow{2}{*}{ شايستَى كَرومَرايى } \\
\hline & & $r V / \Delta V$ & $11 \%$ & 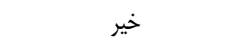 & \\
\hline \multirow{2}{*}{.111} & \multirow{2}{*}{$1 / \Delta \Lambda$} & $\mid V \& / \Delta \Lambda$ & if & 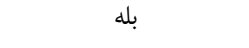 & \multirow{2}{*}{ شايستخى هاى كار آفرينانه (كل) } \\
\hline & & $199 / 9$ & 114 & 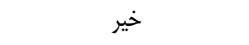 & \\
\hline
\end{tabular}


كروه برابر است. نتايج آزمون t نشان مىدهد اعضاى داراى

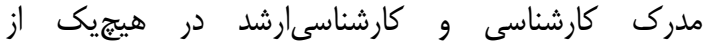

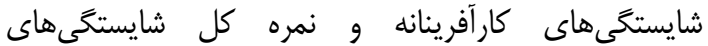
كارآفرينانه تفاوت معنى دارى ندارئن

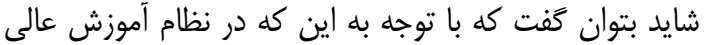

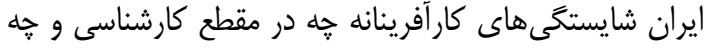

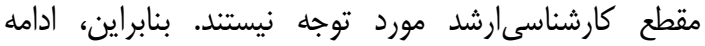

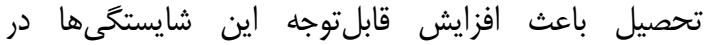
دانشآموختخان كشاورزى نمى شود.
مقايسه ميزان شايستَى هاى كارئى آفرينانه بين اعضاى

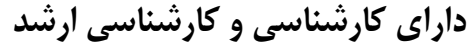

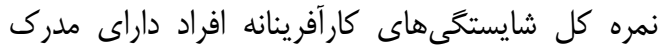

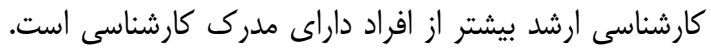

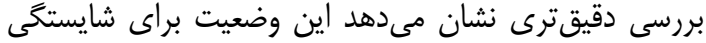

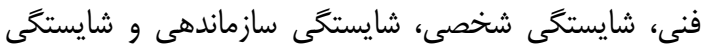

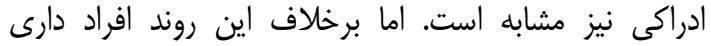

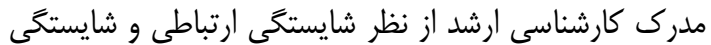

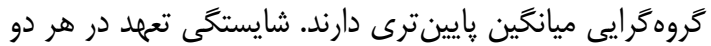

جدول ها - تفاوت شايستخى هاى كارآفرينانه در بين اعضاى داراى مدرى كارشناسى و كارشناسىارشد Table 15. Comparison of means (independent samples t-test) of entrepreneurial competencies of respondents in terms

\begin{tabular}{|c|c|c|c|c|c|c|}
\hline سطح معنى دارى & مقدار t & انحراف معيار & ميانگين & $\mathrm{N}$ & جنسيت & شايستكى \\
\hline \multirow{2}{*}{$\cdot / \kappa^{c}$} & \multirow{2}{*}{$\cdot / M 99$} & $r / Q \Gamma$ & $r \cdot / 1 Q$ & ז & كارشناسى & \multirow{2}{*}{ شايستگى فنى } \\
\hline & & $r / \mu^{\alpha}$ & $r \cdot / A r$ & rq & كارشناسى ارشد & \\
\hline \multirow{2}{*}{ - IMAD } & \multirow{2}{*}{$-1 / 19$} & $F / 9 \Delta$ & $r V / V e^{e}$ & זם & كارشناسى & \multirow[b]{2}{*}{ نايستخى شخصى } \\
\hline & & $F / r$. & $r N / W$ & rq & كارشناسى ارشد & \\
\hline \multirow{2}{*}{ Tא/. } & \multirow{2}{*}{$-\cdot / v r$} & Q/QT & $r q / q$. & ז & كارشناسى & \multirow{2}{*}{ شايستخى سازماندهى } \\
\hline & & $V / \Delta F$ & $r \cdot / \Lambda t$ & rq & كارشناسى ارشد & \\
\hline \multirow{2}{*}{.$/ 91$} & \multirow{2}{*}{.$- / . r$} & $\Delta / r q$ & $r \cdot$ & q & كارشناسى & \multirow{2}{*}{ ثنايستخى ادراكى } \\
\hline & & $\Delta / V$ & $r . / . r$ & н & كارشناسى ارشد & \\
\hline \multirow{2}{*}{.$/ T \Lambda$} & \multirow{2}{*}{$1 / v$} & $F / r$. & $r \Delta / 4)$ & צ & كارشناسى & \multirow{2}{*}{ شايستخى ارتباطى } \\
\hline & & F/VA & $Y \Psi / Q 1$ & rq & كارشناسى ارشد & \\
\hline \multirow{2}{*}{.$/ 99$} & \multirow{2}{*}{.$/ \cdot 1$} & $r / 1$. & $\mid N / 19$ & צ & كارشناسى & \multirow{2}{*}{ شايستخى تعهد } \\
\hline & & $r / \cdot V$ & WT & rq & كارشناسى ارشد & \\
\hline \multirow{2}{*}{.$/ 91$} & \multirow{2}{*}{$\cdot 1$} & $r / M$ & $r / / \Delta q$ & צ & كارشناسى & \multirow{2}{*}{ شايستخى گروهَرايى } \\
\hline & & $r / q r$ & $r \mid / Q)$ & rq & كارشناسى ارشد & \\
\hline \multirow{2}{*}{. /va } & \multirow{2}{*}{ | } & rr/rq & IVT/QT & 9 & كارشناسى & \multirow{2}{*}{ شارآفرينانه (كل) } \\
\hline & & $r \Delta / T V$ & $\mid V^{e} / r$ & rq & كارشناسى ارشد & \\
\hline
\end{tabular}

كشاورزى استان كرمان و همجنين كشور دارد و شركتهاى

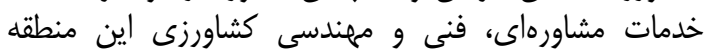

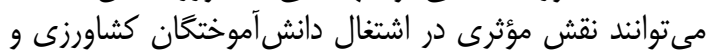

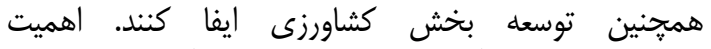

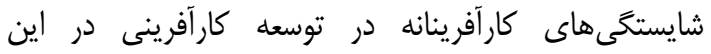

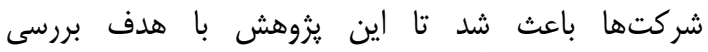

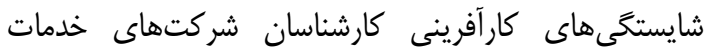

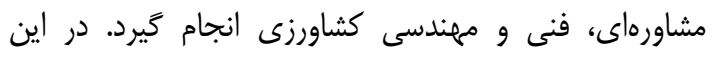

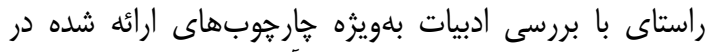

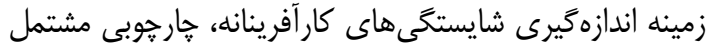

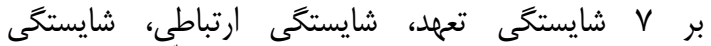

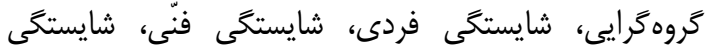

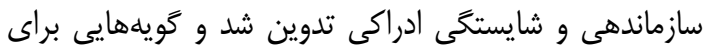

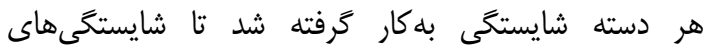

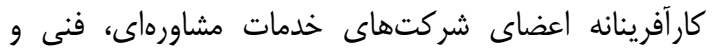

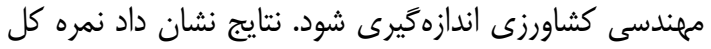

جمعبندى و بيشنههادها

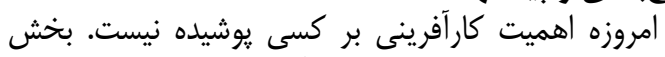

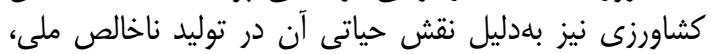

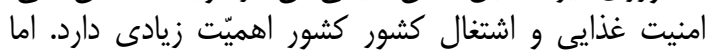

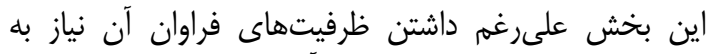

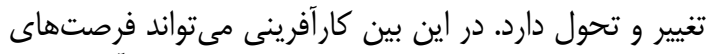

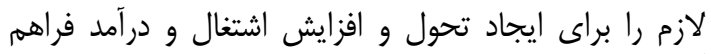

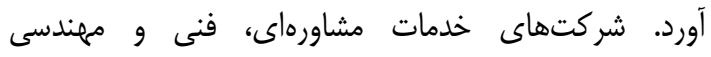

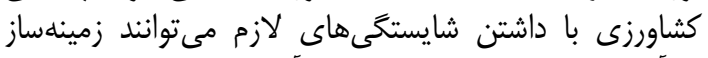

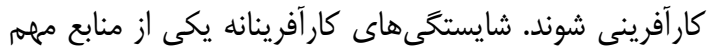

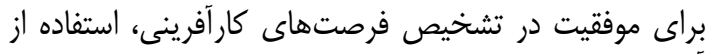

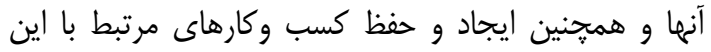

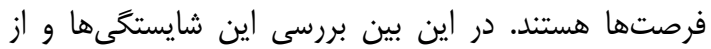

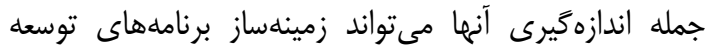

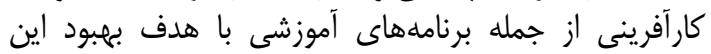

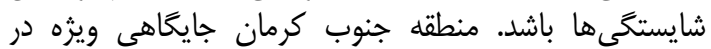




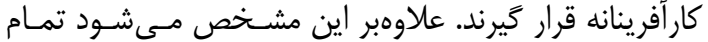

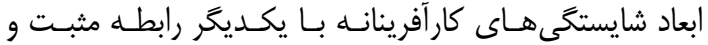

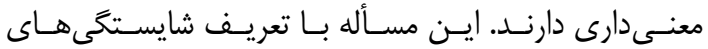

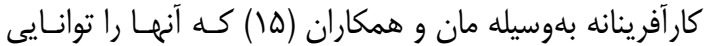

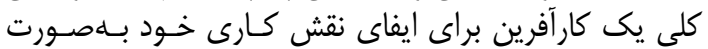

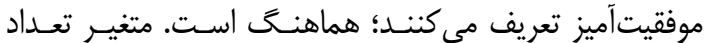

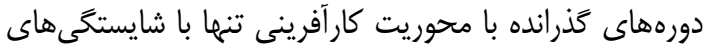

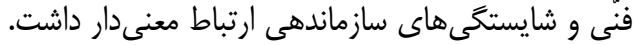

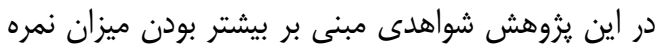

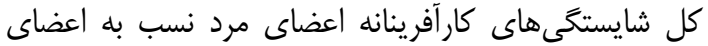

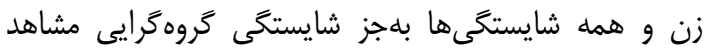

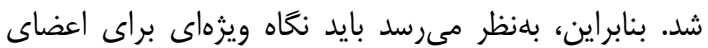

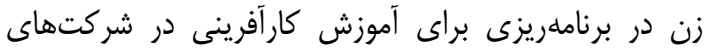

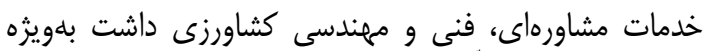

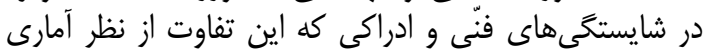

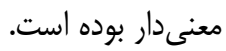
افرادى كه مايل به راهاندازى كسب و كار كار هستند دار دار نمره

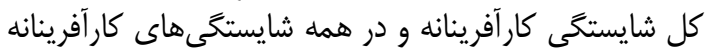

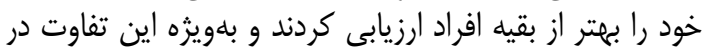

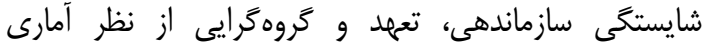

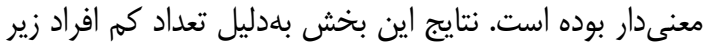

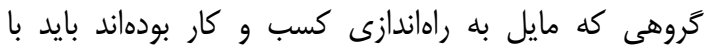

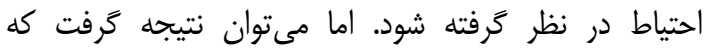

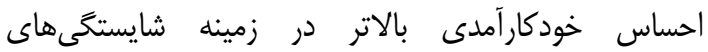
كارآفرينانه مىتواند در تمايل افراد براى رامي راهاندازى كسب و كاري

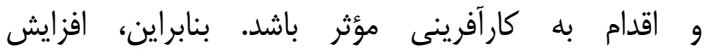

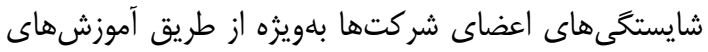

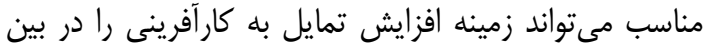

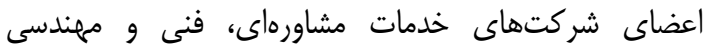

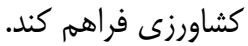

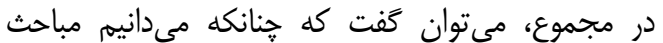

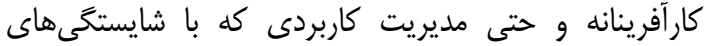

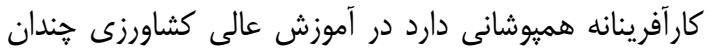

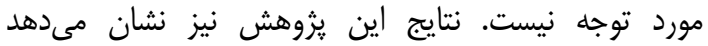

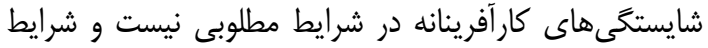

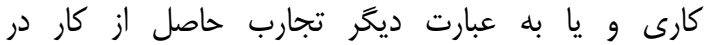

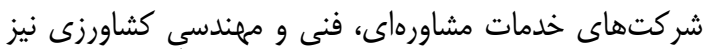

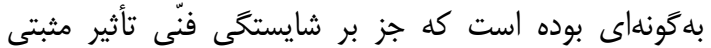

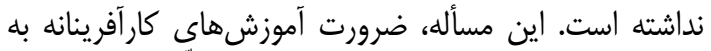

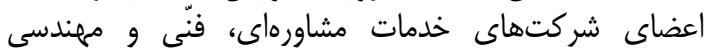

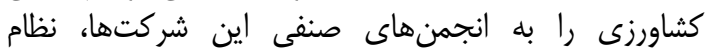

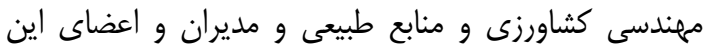

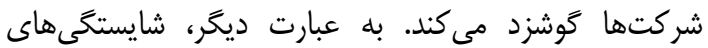

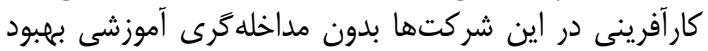

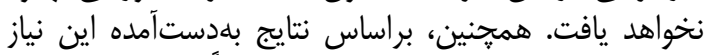

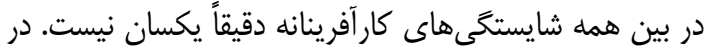

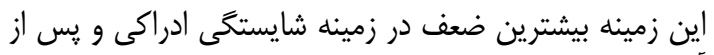

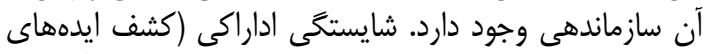
جديد و نكاه نو به مسائل) به توانايى تصميمَّيرى كارئ آفرينانه

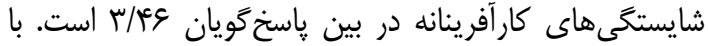

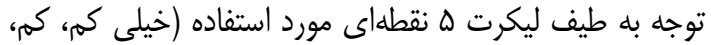

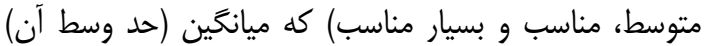

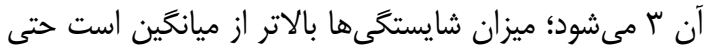

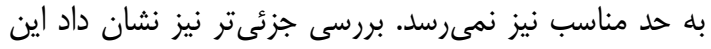

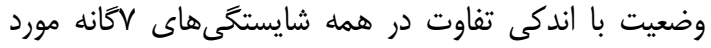

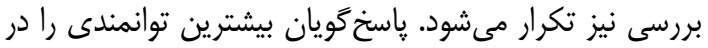

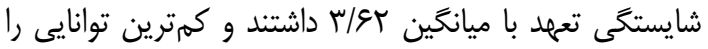

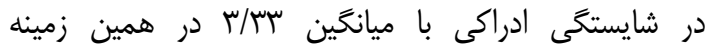

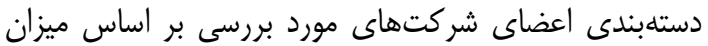

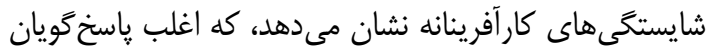

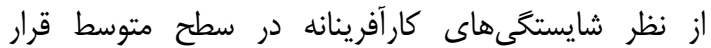
مى كيرند.

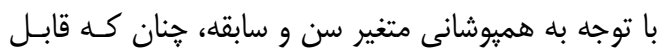

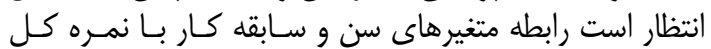

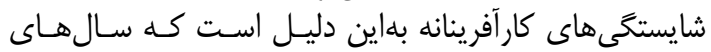

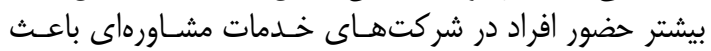

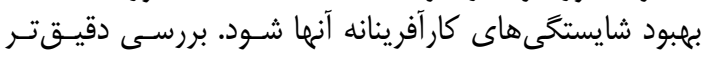

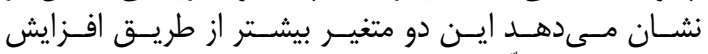

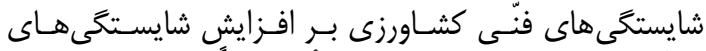

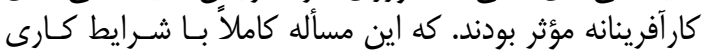

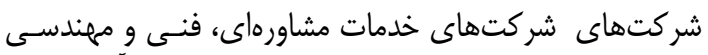

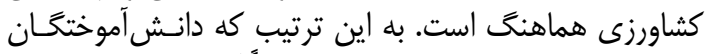

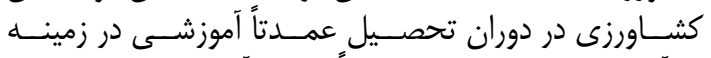

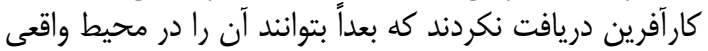

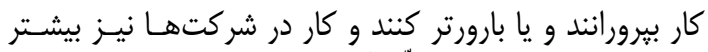

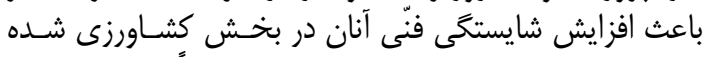

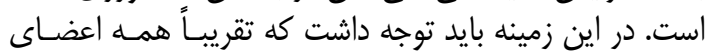

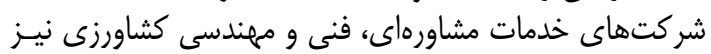

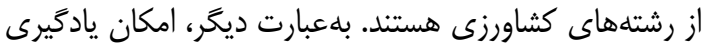

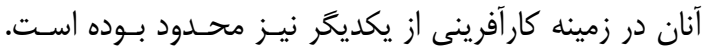

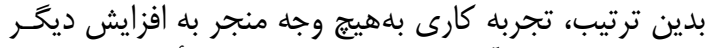

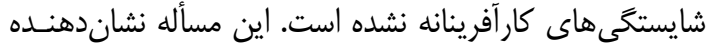

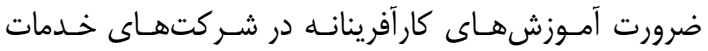

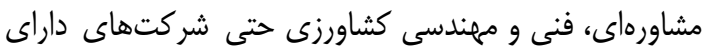

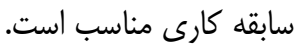

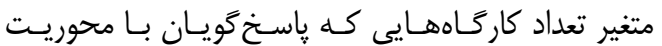

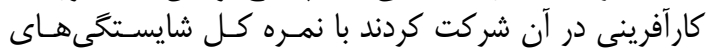

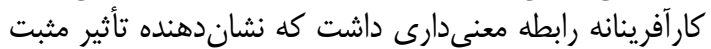

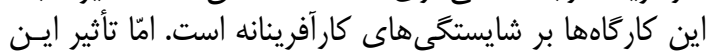

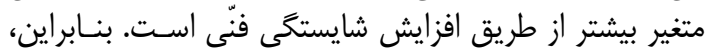

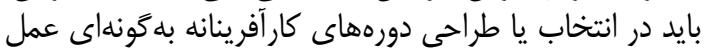

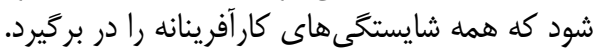

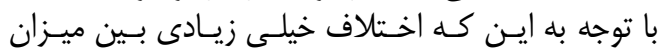

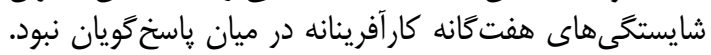

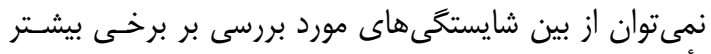

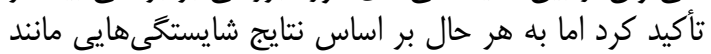

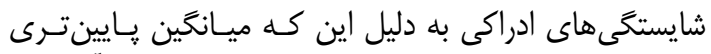

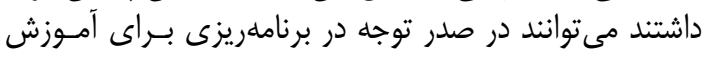




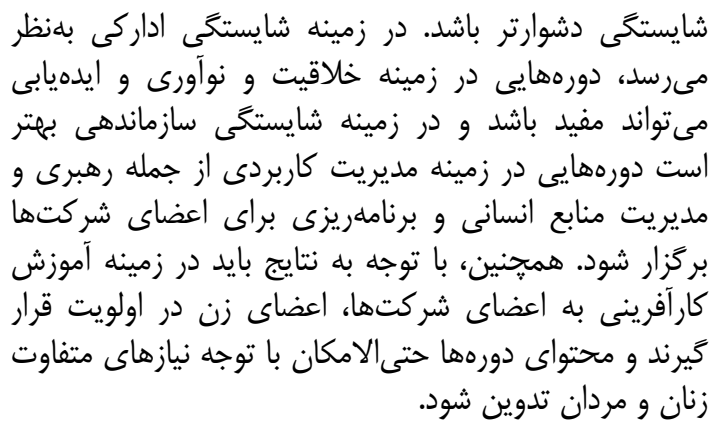

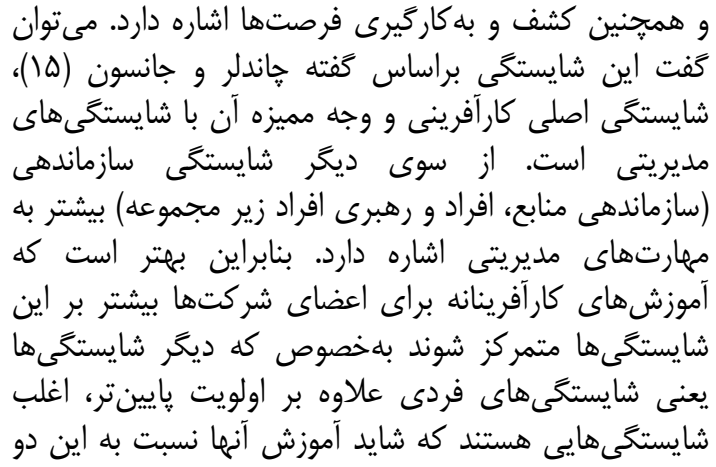

1. Ahmad, N.H. 2007. A cross cultural study of entrepreneurial competencies and entrepreneurial success in SMEs in Australia and Malaysia. Ph.D. Thesis, the University of Adelaide, Adelaide, Australia, $323 \mathrm{pp}$.

2. Ahmad, N.H., T. Ramayah, C. Wilson and L. Kummerow. 2010. Is entrepreneurial competency and business success relationship contingent upon business environment? A study of Malaysian SMEs. International Journal of Entrepreneurial Behavior \& Research, 16(3): 182-203.

3. Ahmad, N.H., Y. Suseno, P.S. Seet, P. Susomrith and Z. Rashid. 2018. Entrepreneurial Competencies and firm performance in emerging economies: a study of women entrepreneurs in Malaysia. In: Ratten V., Braga V. and Marques C. (eds) Knowledge, Learning and Innovation, 5-26.

4. Ahmadpour Dariani, M., H. Nikbin, and A. Karimi. 2012. Factors affecting entrepreneurship development through agricultural advisory services corporations in Zanjan Province. Iranian Journal of Agricultural Economics and Development Research, 42(4): 535-546 (In Persian).

5. Badsar, M., R. Rezaei and R. Darini. 2015. Investigation in the effects of social capital on organizational entrepreneurship in counseling services enterprises in southern kerman province. Iranian Agricultural Extension and Education Journal, 11(1): 145-161 (In Persian).

6. Barney, J. 1991. Firm resources and sustained competitive advantage. Journal of Management, 17(1): 99-120.

7. Bird, B. 1995. Towards a theory of entrepreneurial competency. Advances in Entrepreneurship, Firm Emergence and Growth, 2(1): 51-72.

8. Chandler, G.N. and E. Jansen. 1992. The founder's self-assessed competence and venture performance. Journal of Business Venturing, 7(3): 223-236.

9. Faryabi, M., M. Ahmadvand, and A. Karami. 2017. Survey of Measuring the Importance of Agricultural Development Criteria: An Experimental Study in Southern Kerman. Journal of Agricultural Extension and Education Research, 10(2): 21-34 (In Persian).

10. Fornell, C. and D. Larcker. 1981. Evaluating structural equation modeling with unobserved variables and measurement error. Journal of Marking Research, 18(1): 39-50.

11. Gholami, H. and E. Gholifar. 2018. Entrepreneurship development barriers in isfahan province agricultural engineering, technical and consulting companies: Members' viewpoints. Journal of Entrepreneurship in Agriculture, 4(4): 49-65 (In Persian).

12. Gholami, H., E. Gholifar, J. Ghsemi and M. Baghaei. 2013. An evaluation of the mechanisms of developing entrepreneurship in agricultural advisory service companies in Isfahan Province, Iran. Iranian Journal of Agricultural Economics and Development Research, 43(4): 705-713 (In Persian).

13. Gholamrezai, S., F. Sepahvand, K. Naderi Mehdi and N. Kakolvand. 2017. Analysis the role playing of agricultural and natural resources engineering organization in development of entrepreneurship among related graduates in Khorramabad Township, Journal of Entrepreneurial Strategies in Agriculture, 4(7): 48-56.

14. Khaledi, K. and H. Agahi. 2008. The Role of university on entrepreneurship education. national conference on entrepreneurship development in agricultural applied science and technology education, applied science and technology education institute, Mashhad, Iran (In Persian).

15. Lans, T., R.H.M. Bergevoet, M. Mulder and C.M.J. Van Woerkum. 2005. Identification and measurement of competences of entrepreneurs in agribusiness. In Selected Papers from The 8th Ph. D. Conference on Business Economics, Management and Organization Science, 81-95.

16. Man, W.Y.T., T. Lau and K. Chan, .2002. The competitiveness of small and medium enterprises: A conceptualization with focus on entrepreneurial competencies. Journal of Business Venturing, 17(2): $123-142$.

17. Man, W. Y.T. 2001. Entrepreneurial competencies and the performance of small and medium enterprises in the Hong Kong services sector. Ph.D. Thesis, The Hong Kong Polytechnic University, Kowloon, Hong Kong, 346 pp.

18. Mitchelmore, S. and J. Rowley. 2010. Entrepreneurial competencies: a literature review and development agenda. International Journal of Entrepreneurial Behavior \& Research, 16(2): 92-111.

19. Mitchelmore, S., J. Rowley and E. Shiu. 2014. Competencies associated with growth of women-led SMEs. Journal of Small Business and Enterprise Development, 21(4): 588-601.

20. Mulder, M., T. Lans, J. Verstegen, H. Biemans, and Y. Meijer. 2007. Competence development of entrepreneurs in innovative horticulture. Journal of Workplace Learning, 19(1): 32-44. 
21. Norouzi, A., E. Abbasi and A. Naeimi. 2014. Creativity factor analysis of jihad-e-keshavarzi organization staffs of Ilam province. Journal of Entrepreneurship and Agriculture, 1(2): 96-108.

22. Rasmussen, E., S. Mosey and M. Wright. 2011. The evolution of entrepreneurial competencies: A longitudinal study of university spin off venture emergence. Journal of Management Studies, 48(6): 1314-1345.

23. Rasouliazar, S., S.M. Hosseini, S.J.F. Hosseini and S.M. Mirdamadi. 2011. The investigation perception of agricultural extension agents about affective factors on effectiveness of agricultural advisory services companies in Iran. Journal of American Science, 7(2): 445-451.

24. Reisi, A., M. Sheihaki Tash, H. Salarzehi, A. Valinafs. 2016. Identification and prioritization of factors affecting agricultural entrepreneurship in rural areas (Study Case: Sarbaz County). Journal of Entrepreneurial Strategies in Agriculture, 3(6): 51-58.

25. Rezaei, R., E. Gholifar, L. Safa and M. Kazemi Torbaghan. 2012. Identifying the barriers to corporate entrepreneurship development in Agricultural Consulting, Technical and Engineering Service Ventures (ACTESV) in Zanjan Province. Journal of Entrepreneurship Development, 4(4): 27-46 (In Persian).

26. Sánchez, J.C. 2011. University training for entrepreneurial competencies: Its impact on intention of venture creation. International Entrepreneurship and Management Journal, 7(2): 239-254.

27. Shiri, N., A. Alibaygi and M. Faghiri. 2013. Factors affecting entrepreneurial motivation of agricultural students at Razi University. International Journal of Agricultural Management and Development, 3(3): 175-180.

28. Valliere, D. 2013. Towards a schematic theory of entrepreneurial alertness. Journal of Business Venturing, 28(3): 430-442. 


\title{
Measuring the Entrepreneurial Competencies of Members of Agricultural Engineering, Technical, and Advisory Services Companies (The Case of South of Kerman Province)
}

\section{Hesamedin Gholami ${ }^{1}$ and Jamshid Eghbali ${ }^{2}$}

\author{
1- Assistant Professor, Agricultural Research, Education and Extension Organization (AREEO), Tehran, Iran \\ (Corresponding Author: h.gholami@areeo.ac.ir) \\ 2- PhD. Student, Department of Agricultural Development and Management, University of Tehran, Tehran, Iran \\ Received: November 30, 2017 \\ Accepted: January 5, 2018
}

\begin{abstract}
Entrepreneurial competencies have critical effect on venture enterprises. In this regard, measuring entrepreneurial competencies can be applied in planning for improving these competencies in Agricultural Engineering, Technical, and advisory Companies in south of Kerman province. Thus, the main purpose of this study was to measure entrepreneurial competencies of Agricultural Engineering, Technical, and Advisory Services Companies' experts. Statistical population of this study was consisted of members of mentioned companies from which a sample of 132 members were accessed through stratified proportional sampling method and Cochran formula. Data collected by a questionnaire that its face validity and construct validity were approved, respectively, by a panel of experts and convergent validity (AVE). Study instrument reliability was approved by computing Cronbach alpha and composite reliability. Results revealed that respondents' entrepreneurial competences were upper than moderate level but less than good level (3.46 from 5) and most the respondents ( 72.72 percent) had moderate level of entrepreneurial competences. Furthermore, respondents were most competent in commitment competency and least competent in conceptual competency. Considering the results some recommendations have been provide for entrepreneurship training in studied companies.
\end{abstract}

Keywords: Entrepreneurial Competencies, Entrepreneurial Skills, Competencies, Agribusiness, Agricultural Graduates 